\title{
Tajdidukasi
}

Vol. 9, No. 1, January 2019, pp. 1-6

1

\section{Menanamkan jiwa kepemimpinan dalam pembelajaran ekonomi}

\author{
Enung Hasanah \\ Majelis Pendidikan Dasar dan Menengah Pimpinan Wilayah Muhammadiyah Daerah Istimewa Yogyakarta. \\ Jalan Gedongkuning Nomor 130 B Yogyakarta, Indonesia \\ enung.hs@gmail.com \\ * corresponding author
}

ARTICLE INFO

Keywords

Pembelajaran

Ekonomi

Jiwa kepemimpinan

Teacher,

Young generation

leadership

\section{ABSTRACT}

Indonesia saat ini sedang dilanda krisis moral dan kepemimpinan. Hal ini perlu diantisipasi dengan menanamkan jiwa kepemimpinan generasi muda, sebab setiap anak merupakan bibit bagi masa depan bangsa kita. Artikel ini bertujuan untuk mengkaji: (1) Bagaimanakah cara menanamkan jiwa kepemimpinan pembelajaran ekonomi; (2) Jiwa kepemimpinan apa yang dapat ditanamkan melalui pembelajaran ekonomi? Hasil kajian menunjukan bahwa (1) Cara menanamkan jiwa kepemimpinan peserta didik dalam pembelajaran ekonomi yaitu dengan memberikan berbagai kesempatan dan pilihan bagi peserta didik supaya memahami inti pembelajaran dan melatih mereka untuk dapat menyelesaikan masalah ekonomi di masyarakat. (2) Jiwa kepemimpinan yang dapat ditanamkan dalam pembelajaran ekonomi adalah kemampuan berpikir kritis, mengambil keputusan dan melatih kepercayaan diri.

This is an open access article under the CC-BY-SA license.

\section{PENDAHULUAN}

Indonesia adalah negara yang subur secara alamiah. Namun, kenyataannya kemiskinan masih saja tinggi, hingga maret 2010 saja jumlah penduduk miskin masih sebesar 31.020 .000 jiwa (13,33\%). Tahun 2009, Indeks Pembangunan Manusia (IPM) Indonesia berada pada peringkat ke-111 dari 182 negara. Selain itu, tindakan para koruptor tidak kalah meresahkan bangsa ini. Hal itu menunjukan bahwa Indonesia sedang dilanda krisis moral dan kepemimpinan. Alam demokrasi di Indonesia yang memberi kebebasan kepada setiap rakyatnya, kini malah dijadikan ajang pembenaran pendapat pribadi oleh para (oknum) pemimpin (penguasa) maupun rakyat biasa demi kepuasan pribadinya.

Indonesia kini memerlukan pemimpin hebat sekelas Jenderal Sudirman yang rela mengorbankan kepentingan pribadinya demi bangsa ini. Untuk itu diperlukan upaya-upaya konkrit yang dapat menghasilkan generasi penerus yang berkualitas yang mampu meneruskan tonggak kepemimpinan bangsa secara lebih baik.

Pendidikan merupakan media yang paling efektif untuk membangun jiwa kepemimpinan generasi muda (Handayani \& Rasyid, 2015). Melalui pendidikan, para pemuda akan mendapatkan berbagai pengalaman hidup yang dapat mematangkan kepribadian dan cara berfikirnya. Secara ideal, proses pendidikan harus mampu memberi penguatan-penguatan positif terhadap perkembangan potensi peserta didik baik dari aspek afektif, kognitif, dan psikomotor secara inkoheren. Ketiga aspek tersebut 
seyogyanya dikemas dalam kegiatan pembelajaran aktif yang bersinergi dengan penanaman budaya karakter bangsa.

Mata Pelajaran Ekonomi merupakan bagian dari ilmu sosial yang dipelajari peserta didik tingkat SMA yang fokus pembahasannya mengenai bagaimana memenuhi kebutuhan yang terus meningkat sementara alat pemuas kebutuhannya terbatas. Smentara itu, belajar ilmu sosial merupakan pendidikan afektif melalui latihan profesional, pengalaman hidup, dan nilai-nilai sosial serta nilai kepribadian yang akan menuntun kita dalam mengambil keputusan (Keen et al., 2005). Dengan demikian mata pelajaran ekonomi memiliki potensi yang sangat besar untuk dapat menanamkan jiwa kepemimpinan, baik dari segi materi maupun proses pembelajaran.

\section{Kepemimpinan}

Pemimpin bukanlah orang yang tahu segalanya (Stevenson, 2006, p. 184). Para pemimpin bisa saja tidak memiliki keterampilan praktik dalam politik atau pun bisnis, tetapi mereka mampu memberikan pandangan jauh ke depan dan mampu membuat orang yang dipimpinnya semakin menjadi berhasil dengan mengikuti arahan dari sang pemimpin.

Seorang pemimpin mampu mengambil keputusan tanpa keraguan. Dengan demikian kepemimpinan/leadership memegang peranan yang sangat penting dalam manajemen, bahkan dapat dinyatakan, kepemimpinan adalah inti dari managemen.

McCauley dan Van Velsor (2004) menyatakan bahwa peran dan proses kepemimpinan membutuhkan pembaharuan, harus mampu mengatasi kesulitan, konflik, dan kekecewaan. Kepemimpinan itu sendiri adalah tantangan yang terus dikembangkan. Kemampuan memimpin adalah kemampuan yang berasal dari, dan untuk dirinya sendiri melalui pengalaman yang sudah dilalui dalam hidupnya maupun dari orang lain. Berdasarkan hal itu, jelaslah bahwa kepemimpinan adalah sifat yang sangat kompleks.

Di dunia ini, ada orang-orang yang telah menjadi pemimpin besar tetapi memiliki ambisi pribadi terlalu banyak atau keserakahan, sehingga kepemimpinannya hancur bahkan bisa berakhir di penjara. Maka kemampuan memimpin, bukanlah sekedar mampu mengatur orang lain dan lingkungannya, melainkan juga harus mampu mengatur dan memimpin diri sendiri berdasarkan moralitas dan keyakinan terhadap Tuhan.

Kepemimpinan itu sendiri adalah kemampuan untuk membuat orang bersemangat tentang tujuan dan membimbing mereka untuk mencapainya. Pemimpin sering bergantung pada orang lain untuk mencapai tujuan. Tapi para pemimpin memiliki bakat dan merupakan orang-orang inspiratif dan bermanfaat.

Kepemimpinan memerlukan tanggungjawab yang sangat besar. Seorang pemimpin harus menghormati orang-orang yang mengikuti dia dan mengakui bahwa seorang pemimpin tidak ada artinya tanpa adanya orang yang dia pimpin. Seorang pemimpin yang baik harus mendengarkan saran dan menghargai mereka yang bekerja keras.

Terdapat banyak teori dan tipe kepemimpinan. Tetapi, model kepemimpinan dalam makalah ini menekankan bagaimana membentuk peserta didik yang memiliki jiwa kepemimpinan yang kharismatik. Sebab model kharismatik ini memiliki beberapa keunggulan dibanding model lain.

Robert House menyampaikan teorinya bahwa kepemimpinan yang efektif menggunakan memiliki kharisma, memiliki keyakinan diri, mampu mempengaruhi, dan menampilkan moralitas tinggi untuk meningkatkan karismatiknya. Dengan kharismanya pemimpin transformational akan menantang bawahannya untuk melahirkan karya istimewa. Langkah yang dilaksanakan pemimpin ini biasanya membicarakan dengan pengikutnya bagaimana pentingnya kinerja mereka, bagaimana bangga dan yakinnya mereka sebagai anggota kelompok, bagaimana istimewanya kelompok yang akan menghasilkan karya luar biasa (House \& Mitchell, 1975).

Menurut Bass \& Avilio (Conger \& Kanungo, 1994, p. 14) bahwa terdapat empat ciri utama tipe pemimpin kharismatik transformational yaitu: kharismatik dan mampu mempengaruhi orang lain, inspiratif, memiliki karakter intelektual, dan memiliki pertimbangan individual. 
Kharisma menyangkut dua hal penting yaitu prilaku pemimpin dan reaksi pengikutnya, seperti kepercayaan terhadap kemampuan pemimpinnya. Inspiratif merupakan kemampuan untuk memberi inspirasi kepada orang lain. Karakter intelektual yaitu kemampuan untuk berfikir smart (berpikir kritis), serta pertimbangan individu artinya kemampuan dirinya untuk menyelesaikan masalah berdasarkan pengalaman dan kemampuan yang dimilikinya.

\section{Menanamkan jiwa kepemimpinan dalam pembelajaran ekonomi}

Apa yang dimaksud dengan ekonomi? Ekonomi muncul karena adanya kebutuhan manusia. Tujuan dan definisi pendidikan ekonomi adalah untuk menganalisis bagaimana barang-barang dan jasa dapat diproduksi dan didistribusikan guna memenuhi kebutuhan manusia (Ediger, 1997). Ekonomi tidak hanya berbicara tentang individu sebagai bagian dari sebuah sistem ekonomi, konsumen, sebuah usaha, perserikatan, dan pasar produksi, tetapi juga tentang seluruh bagian konstitusi sistem ekonomi dalam suatu negara, yang menjelaskan bagaimana seorang individu dapat berinteraksi dengan lingkungannya secara umum (Ellis, 2010). Selain itu, dengan adanya ilmu ekonomi diharapkan dapat membentuk suatu sistem produksi dan distribusi yang dapat bekerja lebih baik di bawah komando pemerintah sebagai pemilik kebijakan. Jadi mata pelajaran ekonomi itu merupakan satu set pengetahuan dan cara pikir mengenai kehidupan bermasyarakat dalam rangka memenuhi kebutuhan hidup manusia.

Ekonomi sebagai suatu pengetahuan terdiri dari konsep, generalisasi, dan teori-teori yang dibangun oleh orang-orang yang berusaha untuk memperpanjang nilai guna sumber daya alam, sumber daya manusia, dan sumber daya modal yang terbatas, sementara kebutuhan manusia tidak terbatas. Kunci terpenting dalam pembelajaran ekonomi adalah bagaimana sistem berpikir manusia supaya dapat mengambil keputusan ekonomi di antara beberapa alternatif yang tersedia. Keputusan yang diambil diharapkan merupakan keputusan ideal yang bermanfaat bagi dirinya sendiri dan masyarakat umum. Dengan demikian, output dari proses pembelajaran ekonomi secara ideal adalah dapat menghasilkan para pemimpin muda yang mampu menyelesaikan masalah dan mengambil keputusan ekonomi berdasarkan pengalaman, pengetahuan, kekuatan diri, keyakinan, dan moralitas yang tinggi.

Lalu bagaimana implementasinya dalam pembelajaran ekonomi? Pembelajaran yang efektif bukanlah sekedar mentransfer pengetahuan melainkan mampu menciptakan sesuatu perubahan yang positif melalui berbagai proses belajar yang didasari oleh keyakinan guru itu sendiri (Feiman-Nemser \& Buchmann, 2005, pp. 223-224). Hal tersebut sejalan dengan pendapat Brown (2006: 2) bahwa Evidence for the interconnection of these beliefs is scarce, yet there is a recurring theme that what teachers believe about one area of instruction (e.g., teaching or curriculum) impacts on practices and conceptions in other important domains (assessment or learning).

Guru harus yakin bahwa mengajar merupakan komitmen jangka panjang untuk mengerahkan segala kemampuan kita untuk membantu orang muda mengembangkan segi intelektual, emosi, dan prilaku (Partin, 2009, p. 22). Supaya potensi yang dimiliki peserta didik dapat berkembang secara optimal, mereka perlu kesempatan belajar dengan strategi yang bervariasi (Doel \& Shardlow, 2005; Rahayuningsih et al., 2018). Penerapan berbagai strategi pembelajaran akan menghasilkan pembelajaran yang efektif (Voltz et al., 2010; Widayanti, 2019).

Melalui perpaduan beberapa metode pembelajaran aktif yang diintegrasikan dengan pendidikan karakter budaya bangsa, peserta didik diberikan kebebasan untuk mengadakan pengamatan, pengklasifikasian, penafsiran, peramalan, penerapan, perencanaan, penelitian berdasarkan nilai moral yang dijadikan pedoman sikap dan mengkomunikasikan hasil pendidikan dalam kegiatan pembelajaran. Berdiskusi dengan sportif, belajar dengan sungguh-sungguh ataupun menghargai pendapat orang lain, mengemukakan pendapat dengan pertimbangan moralitas, dan berusaha memahami makna pembelajaran bagi kehidupan nyata, merupakan bagian dari proses belajar untuk memiliki jiwa kepemimpinan.

\section{Keterampilan mengambil keputusan ekonomi}

Pokok permasalahan dalam ekonomi adalah scarcity. Setiap orang setiap hari dituntut untuk menentukan pilihan dan mengambil keputusan guna mengatasi kelangkaan, baik dalam hal produksi, konsumsi, maupun distribusi. Tindakan ini tentunya bertujuan supaya tidak mengakibatkan biaya 
peluang yang terlalu besar. Biaya peluang merupakan kesempatan yang ditinggalkan karena memilih hal yang lain.

Seorang pemimpin yang transformatik harus mampu mengambil keputusan atas dasar pertimbangan moralitas yang tinggi dan harus mampu meyakinkan orang lain bahwa apa yang diputuskannya adalah sesuatu yang benar. Dalam hal ini guru dapat mengajari peserta didik untuk melakukan beberapa langkah sebelum mengambil keputusan yaitu mengidentifikasi berbagai alternatif, membuat kriteria, dan menetapkan konsekuen yang akan terjadi apabila mengambil keputusan tertentu.

Langkah-langkah tersebut merupakan proses belajar untuk memiliki karakter intelektual yang tinggi yaitu berlatih berpikir kritis. Pengertian kemampuan berpikir kritis sampai sekarang masih banyak yang memperdebatkan. Namun melihat tujuannya intinya sama yaitu menunjuk pada kemampuan seseorang menggunakan akal dan pikirannya dalam menyelesaikan suatu masalah dan mengambil keputusan. Meskipun Bloom, mengatakan bahwa kemampuan berpikir masih berada dalam ranah kognitif (Sujana, 2000). Tetapi kemampuan berpikir merupakan ranah kognitif tingkat paling tinggi. Dalam hal ini, (Sujana, 2000) mengelompokan kemampuan berpikir sebagai keterampilan intelek. Keterampilan intelek berhubungan dengan kegiatan untuk memecahkan masalah, menyelenggarakan penelitian, melakukan perencanaan, mengerjakan soal-soal statistik dan matematik, membuat proposal dan lain-lain. Keterampilan intelek lebih menekankan pada peningkatan kemampuan berpikir rasional. Kemampuan berpikir rasional sangat penting bagi seorang pemimpin dalam mengambil keputusan.

Proses pengambilan keputusan dapat dilakukan secara lebih konkrit melalui, (1) Melakukan investigasi tentang permasalahan yang familiar dengan peserta didik. (2) Menggunakan tabel pengambilan keputusan yang memuat alternatif pilihan dan konsekuensi yang akan diterima atas keputusan yang diambil Menurut (Ediger, 1997).

Berikut ini adalah contoh tabel pengambilan keputusan dan konsekuensi yang harus ditentukan oleh peserta didik secara berkelompk pada materi biaya peluang. Misalnya guru menyodorkan tentang rencana pemetintah untk menaikan tarif dasar listrik. Kemudian peserta didik diarahkan untuk bekerja secara kelompok menganalisis kemungkinan baik atau tidaknya kebijakan tersebut bagi masyarakat dalam jangka panjang maupun jangka pendek.

Tabel 1. Tabel konsekuensi pengambilan keputusan haruskah tarif dasar listrik di Indonesia dinaikan

\begin{tabular}{ccc}
\hline Alternatif & Konsekuensi & \\
\cline { 2 - 4 } & & \\
Ya & & Jangka Pendek \\
Tidak & & \\
\hline
\end{tabular}

Tabel 1 menunjukan sebuah tantangan bagi peserta didik dalam hal memprediksi akibat dari kebijakan pemerintah dalam menaikan Tarif Dasar Listrik (TDL) dalam jangka pendek maupun jangka panjang. Dalam tabel tersebut juga meliputi tanggapan negatif juga positf tentang kebijakan tersebut. Setelah peserta didik melengkapi tabel, kemudian mereka akan berdiskusi tentang penting tidaknya dan peluang tentang kebijakan pemerintah tersebut.

Pengambilan keputusan akhir, sangatlah penting, sebagai sebuah latihan menjadi seorang pemimpin, bukan hanya melatih intelektual. Memberi kesempatan peserta didik untuk mengambil keputusan dan mengenalkan peserta didik untuk hidup dengan segala konsekuensi atas pilihannya merupakan hal penting dan nilai kepemimpinan yang realistis.

Tabel pengambilan keputusan ini, kemudian dipresentasikan oleh masing-masing kelompok peserta didik. Proses presentasi tersebut merupakan bentuk proses pembelajaran yang menanamkan kepercayaan diri dan proses berlatih untuk dapat berkominikasi dengan baik bagi peserta didik. Kebiasaaan berbicara di depan umum, mempresentasikan materi hasil penemuan sendiri di depan kelas, akan dapat mendorong peserta didik untuk memiliki kemampuan menjadi seorang pemimpin yang kharismatik. Dengan keberanian untuk tampil di muka kelas, maka mental peserta didik akan terlatih untuk menjadi orang yang percaya diri. Meske demikian, rasa percaya diri itu perlu dibarengi dengan rasa hormat kepada orang lain. Sebagaimana diungkapkan (Stevenson, 2006) bahwa beberapa orang memang ada 
yang terlahir dengan memiliki kemampuan alami sebagai pemimpin. Setiap orang akan mendengarkan mereka dengan antusias. Tetapi jika seseorang tidak memiliki kepemimpinan natural, dia bisa membangunnya melalui proses pendidikan. Untuk menjadi seorang pemimpin yang didengarkan orang lain, dapat dilatih melalui latihan komunikasi, belajar bagaimana supaya orang lain antusias dan mau mendengarkan visi anda, yaitu dengan memperlakukan orang lain secara hormat (Stevenson, 2006).

Teori dari Stevenson ini bukanlah hal yang baru, memperlakukan orang lain secara terhormat sama dengan menghormati diri sendiri. Maka dalam proses pembelajaran para guru harus selalu mengingatkan dan memberi contoh bagaimana cara berkomunikasi yang baik, yang sesuai dengan tuntutan moral dan etika di masyarakat.

\section{SIMPULAN}

Menanamkan jiwa kepemimpinan bukanlah hal yang mudah, karena kepemimpinan merupakan sesuatu yang komplek. Tetapi, jiwa kepemimpinan dapat dibina dan ditanamkan pada peserta didik sebagai generasi calon pemimpin masa depan melalui proses pembelajaran yang benar yaitu dengan memberi contoh konkrit, dan memadukan berbagai strategi pembelajaran aktif di kelas.

Proses pembelajaran hendaknya mampu melibatkan aspek kognitif, afektif, maupun psikomotorik secara seimbang. Melalui proses pembelajaran aktif, peserta didik akan terlatih untuk selalu memiliki kepercayaan diri, berpikir kritis, dan mengambil keputusan yang tepat, sebagaimana seorang pemimpin sejati.

\section{REFERENSI}

Conger, J. A., \& Kanungo, R. N. (1994). Charismatic leadership in organizations: Perceived behavioral attributes and their measurement. Journal of Organizational Behavior, 15(5), 439452. https://doi.org/10.1002/job.4030150508

Doel, M., \& Shardlow, S. M. (2005). Modern social work practice: Teaching and learning in practice settings. Ashgate Publishing, Ltd.

Ediger, M. (1997). Social studies and the middle school student. Journal of Instructional Psychology, 24(3), 188.

Ellis, A. K. (2010). Teaching and learning elementary social studies. Pearson/Allyn \& Bacon.

Feiman-Nemser, S., \& Buchmann, M. (2005). Knowing, thinking and doing in learning to teach: A research framework and some initial results. In Teacher Thinking \& Professional Action (pp. 239-250). Routledge.

Handayani, T., \& Rasyid, A. A. (2015). Pengaruh kepemimpinan kepala sekolah, motivasi guru, dan budaya organisasi terhadap kinerja guru SMA Negeri Wonosobo. Jurnal Akuntabilitas Manajemen Pendidikan, 3(2), 264-277. https://doi.org/10.21831/amp.v3i2.6342

House, R. J., \& Mitchell, T. R. (1975). Path-goal theory of leadership. Washington Univ Seattle Dept Of Psychology.

Keen, M., Brown, V. A., \& Dyball, R. (2005). Social learning in environmental management: towards a sustainable future. Routledge.

McCauley, C. D., \& Van Velsor, E. (2004). The center for creative leadership handbook of leadership development (Vol. 29). John Wiley \& Sons.

Partin, R. L. (2009). Kiat nyaman mengajar di dalam kelas. Indeks.

Rahayuningsih, R. S., Fajaruddin, S., \& Manggalasari, L. C. (2018). The implementation of total quality management in vocational high schools. Psychology, Evaluation, and Technology in Educational Research, 1(1), 31-40. https://doi.org/10.33292/petier.v1i1.20

Stevenson, N. (2006). Young person's character education handbook. JIST life.

Sujana, D. (2000). Strategi pembelajaran dalam pendidikan luar sekolah. Bandung: Nusantara Press.

Voltz, D. L., Sims, M. J., \& Nelson, B. (2010). Connecting teachers, students, and standards: 
Strategies for success in diverse and inclusive classrooms: strategies for success in diverse and inclusive classrooms. ASCD.

Widayanti, E. (2019). The implementation of problem based learning and jigsaw model learning to improve basic programming learning outcomes. International Journal of Education and Learning, 1(2), 89-97. https://doi.org/10.31763/ijele.v1i2.53 